\title{
CELLULAR COMPOSITION OF LYMPHOID TISSUE OF PEYER'S PATCH OF DUODENUM IN DUCKS
}

T. A. MAZURKEVYCH, Candidate of Veterinary Sciences, Associate Professor Academician Volodymyr Kasyanenko Department of Animal Anatomy, Histolo-

gy and Pathomorphology

https://orcid.org/0000-0002-1294-5939

National University of Life and Environmental Sciences of Ukraine, Kyiv, Ukraine

E-mail:mazur@faust.kiev.ua

\begin{abstract}
The aim of our research was to study the cell composition of the lymphoid tissue of the duodenal Peyer's patch of the ducks in age-related aspects. Among the cells of the lymphoid tissue of the duodenal Peyer's patch are immunoblasts, lymphocytes, proplasmocytes, and plasma cells, monocytes and macrophages, epithelial cells, reticular cells, erythrocytes, granulocytes, fibroblasts, and M-cells. The content of populations of these cells is not the same. Lymphocytes in the preparations-imprints are found the most. They are represented by small, medium, and large forms. Small lymphocytes were found in the largest number, and large ones - in the smallest. The content of small lymphocytes decreases unevenly with the age of ducks, and medium and large lymphocytes - increases unevenly. The content of immunoblasts in the lymphoid tissue of the duodenal Peyer's patch of ducks is less than that of lymphocytes. This index decreases unevenly from the 1st to the 420 days of age of birds. Proplasmocytes and plasmocytes are found in the lymphoid tissue of the duodenal Peyer's patch of ducks in small numbers from the 15th day of age. Their content increases significantly with the increasing of the birds' age. The content of macrophages and monocytes in the lymphoid tissue of the duodenal Peyer's patch of ducks is insignificant. Uneven increase of this indicator is registered from the 1st to the 420 days of age of birds. The content of reticular cells cannot be calculated because they are covered by lymphoid cells, and fibroblasts, erythrocytes, granulocytes, and M-cells that occur in the imprint preparations in small quantities cannot be statistically processed.
\end{abstract}

Keywords: ducks, duodenum, Peyer's patch, lymphoid tissue, immunoblasts, lymphocytes, proplasmocytes, plasmocytes, monocytes, macrophages

\section{Introduction}

It is well known that the organs of hemo- and lymphopoiesis include central (primary) and peripheral (secondary) organs, as well as focal clusters of lymphocytes scattered throughout the body, including lymphocytes circulating in the bloodstream and lymph (Day \& Schultz, 2014; Kaushansky et al., 2016). A special place in this multicomponent tissue organization is given to the so- 
called lymphoid tissue associated with mucous membranes (mucous associated lymphoid tissue - MALT). In birds, MALT is formed by lymphoid cells, which are localized in their own plate and submucosal basis of the mucous membrane of the gastrointestinal tract (GALT) and respiratory tract (BALT) (Day \& Schultz, 2014; Kaushansky et al., 2016). These structures form the first protective barrier against antigens that enter the body with food and air. Interest in GALT in birds is currently growing, due to the fact that the vast majority of antigens enter the body of these animals through the digestive organs (Forchielli $\&$ Walker, 2005). As a result, about 70\% of the lymphoid tissue, which forms the parenchyma of peripheral organs of immunogenesis, including GALT structures that comprise Peyer's patches, is localized in their walls (Neutra et al., 2001).

All functions of lymphoid tissue provide its cellular elements from polypotent stem cells to effector cells (lymphocytes, plasma cells, macrophages), which are in the processes of proliferation, differentiation, migration, cooperation, and apoptosis (Regoli et al., 1994; Trufakin et al., 2005). The optimal balance of immunocompetent cells provides its main function - immunity. We did not find information on the cellular composition of the lymphoid tissue of the duodenal Peyer's patch of the ducks in the special literature. Therefore, the study of this issue is relevant.

\section{Materials and methods of researches}

Intestines were obtained from the Blahovarsky cross broiler ducks of 1,5 , $10,15,20,25,30,60,90,120,150,180$, 210,240 days old ( 5 ducks per group). All interventions and slaughter of the birds were performed in compliance with the requirements of the European Convention for the Protection of Vertebrate Animals Used for Experimental and Scientific Purposes (Council of Europe, 1987) and the Decree of the First National Congress on Bioethics (Reznikov, 2003).

Cytological examinations were performed on imprint preparations stained with commercial stains LeikoDiff 200 (Erba Lachema, Czech Republic) and with Pappenheim's stains Hemacolor (Merck, Germany) (Silverman \& Frable, 1990; Storc et al., 2005). The slides were examined with a bright-field microscope "Olympus" (Japan). In imprint preparations, cells were differentiated and their number was counted in 5 fields of view of the microscope (in one preparation). 50-70 cells were counted in one field of the microscope (Avtandilov, 1990).

The arithmetic mean was determined statistically with the error of the arithmetic mean (SD). Statistical analysis was performed by StatSoft Statistica 13.1 (1998).

\section{Results of the research and their discussion}

Immunoblasts, lymphocytes, proplasmocytes and plasmocytes, monocytes and macrophages, epithelial cells, reticular cells, erythrocytes, granulocytes, and M-cells were found in imprint preparations of the lymphoid tissue of the Peyer's patch in ducks by age-related studies. The presence of these cells in the immune formations of the intestines in birds has been reported by other researchers (Burns \& Maxwell, 1986; Havrylin et al., 2014; Barsukova et al., 2015; Qu, 2018). The content of these cell populations is not the same (Tables 1, 2). The content of reticular 
cells cannot be calculated because they are covered by lymphoid cells, and fibroblasts, erythrocytes, granulocytes, and M-cells occur in the imprint preparations in small quantities that cannot be statistically processed.

Lymphocytes are mostly found among the cells (Table 1). They have a structure similar to that in mammals and other birds. The lymphocytes on the imprint preparations have a predominantly round shape and a large basophilic nucleus, which occupies almost the entire volume of the cell (Fig. 1). The shape of the nuclei is different. They can be rounded and slightly elongated. The contours of the nuclei are uneven. A lot of heterochromatin is attached to the inner membrane of their cell wall. The latter, in the form of grains and lumps, is also freely present throughout the nucleoplasm. The nucleolus in the nucleus is difficult to differentiate due to the high content of heterochromatin. The cytoplasmic vol- ume of lymphocytes is insignificant. It surrounds the nucleus in the form of a thin weakly basophilic strip.

The lymphocytes content in ducks of the studied age groups decreases unevenly, which, in our opinion, is due to their differentiation into effector cells. Thus, in one-day-old this indicator is $65.32 \pm 0.39 \%$, and in 420-day-old $-55.97 \pm 0.32 \%$. The content of lymphocytes decreases most intensively in ducks in age from 10 to 15 days (by $2.95 \%$ ).

Among lymphocytes are small, medium, and large. Their content is also different (Table 2). Small lymphocytes are found most in ducks of all ages. Their diameter is up to 7 microns. Small lymphocytes have a large nucleus. Due to the high heterochromatin content, it is intensely stained. The nucleus is surrounded by a narrow strip of cytoplasm. The cytoplasm of small lymphocytes has a form of a crescent-shaped strip,

\section{The content of cells in the Peyer's patch of the duodenum in ducks $(M \pm m, \%)$}

\begin{tabular}{|l|c|c|c|c|}
\hline $\begin{array}{c}\text { Age, } \\
\text { days }\end{array}$ & Immunoblasts & Lymphocytes & $\begin{array}{c}\text { Proplasmocytes } \\
\text { and plasmocytes }\end{array}$ & $\begin{array}{c}\text { Monocytes and } \\
\text { macrophages }\end{array}$ \\
\hline 1 & $32.64 \pm 0.36$ & $65.32 \pm 0.39$ & - & $2.04 \pm 0.09$ \\
\hline 5 & $32.53 \pm 0.24$ & $65.09 \pm 0.25$ & - & $2.38 \pm 0.09$ \\
\hline 10 & $32.52 \pm 0.09$ & $64.76 \pm 0.21$ & - & $2.73 \pm 0.17$ \\
\hline 15 & $31.49 \pm 0.26$ & $62.86 \pm 0.24$ & $2.52 \pm 0.11$ & $3.14 \pm 0.19$ \\
\hline 20 & $31.63 \pm 0.35$ & $61.91 \pm 0.11$ & $2.77 \pm 0.16$ & $3.69 \pm 0.18$ \\
\hline 25 & $30.28 \pm 0.17$ & $61.53 \pm 0.17$ & $3.63 \pm 0.10$ & $4.56 \pm 0.23$ \\
\hline 30 & $28.04 \pm 0.19$ & $60.88 \pm 0.19$ & $6.91 \pm 0.28^{*}$ & $4.17 \pm 0.07$ \\
\hline 60 & $26.51 \pm 0.49$ & $60.89 \pm 1.42$ & $9.21 \pm 0.78$ & $3.39 \pm 0.25$ \\
\hline 90 & $25.59 \pm 0.76$ & $60.94 \pm 0.75$ & $10.41 \pm 0.61$ & $3.06 \pm 0.59$ \\
\hline 120 & $25.94 \pm 0.19$ & $60.25 \pm 0.26$ & $9.19 \pm 0.37$ & $4.62 \pm 0.16$ \\
\hline 150 & $24.06 \pm 0.29$ & $59.65 \pm 0.80$ & $9.66 \pm 0.44$ & $6.63 \pm 0.26^{*}$ \\
\hline 180 & $24.72 \pm 0.37$ & $58.94 \pm 0.19$ & $9.54 \pm 0.26$ & $6.79 \pm 0.25$ \\
\hline 210 & $25.86 \pm 0.26$ & $58.23 \pm 0.27$ & $9.85 \pm 0.23$ & $6.07 \pm 0.17$ \\
\hline 240 & $24.76 \pm 0.16$ & $56.58 \pm 0.26$ & $11.24 \pm 0.23$ & $7.42 \pm 0.13$ \\
\hline 330 & $24.15 \pm 0.11$ & $56.99 \pm 0.27$ & $10.83 \pm 0.12$ & $8.02 \pm 0.24$ \\
\hline 420 & $24.48 \pm 0.08$ & $55.97 \pm 0.32$ & $11.13 \pm 0.35$ & $8.42 \pm 0.28$ \\
\hline
\end{tabular}

Note: $* \mathrm{P}<0.05$ compared to the previous age group. 
which does not completely surround the nucleus (Fig. 1). The content of these lymphocytes decreases unevenly from age of one-day $(52.27 \pm 0.51 \%)$ to 420 day $(48.65 \pm 0.49 \%)$. The content of small lymphocytes decreases most intensively in ducks from 60 to 90 days of age (by $9.71 \%$ ).

Medium lymphocytes are larger $(\mathrm{d}=7-10 \mu \mathrm{m})$ than small ones. They have a larger volume of cytoplasm and nucleus. In their nucleus, the heterochromatin content is slightly lower, as a result of which they have a less intense colour (Fig. 1). The content of medium lymphocytes in the lymphoid tissue of the duodenal Peyer's patch in ducks of the studied age groups decreases unevenly (Table 2). Thus, in 1-day-old birds, this indicator is $40.10 \pm 0.82 \%$, while in 420-day-old $-36.96 \pm 0.43 \%$. The content of medium lymphocytes increases more intensively in ducks aged from 30 to 60 days (by 7.68\%).
The content of large lymphocytes on the imprint preparations is the lowest. The volume of their cytoplasm and nucleus is the largest (Fig. 1). The nucleus is weakly basophilic, contains small lumps of heterochromatin. The cytoplasm is manifested in the form of a thin weakly basophilic strip. The content of large lymphocytes in ducks of the studied age groups increases unevenly (Table 2). In 1-day-old birds their content is $7.63 \pm 0.67 \%$, and in 420 -day-old birds $-14.39 \pm 0.68 \%$. The most intensive increase in the content of large lymphocytes (by $52.06 \%$ ) is observed in ducks from 30 to 60 days of age.

Immunoblasts - cells of the fifth class of lymphocytopoiesis, precursors of effector cells of lymphocytes (Davison et al., 2008). Their size is larger than small and medium lymphocytes. Immunoblasts have a shape from round to slightly elongated. The volume of their cytoplasm is much larger than that of lymphocytes (Fig. 2).

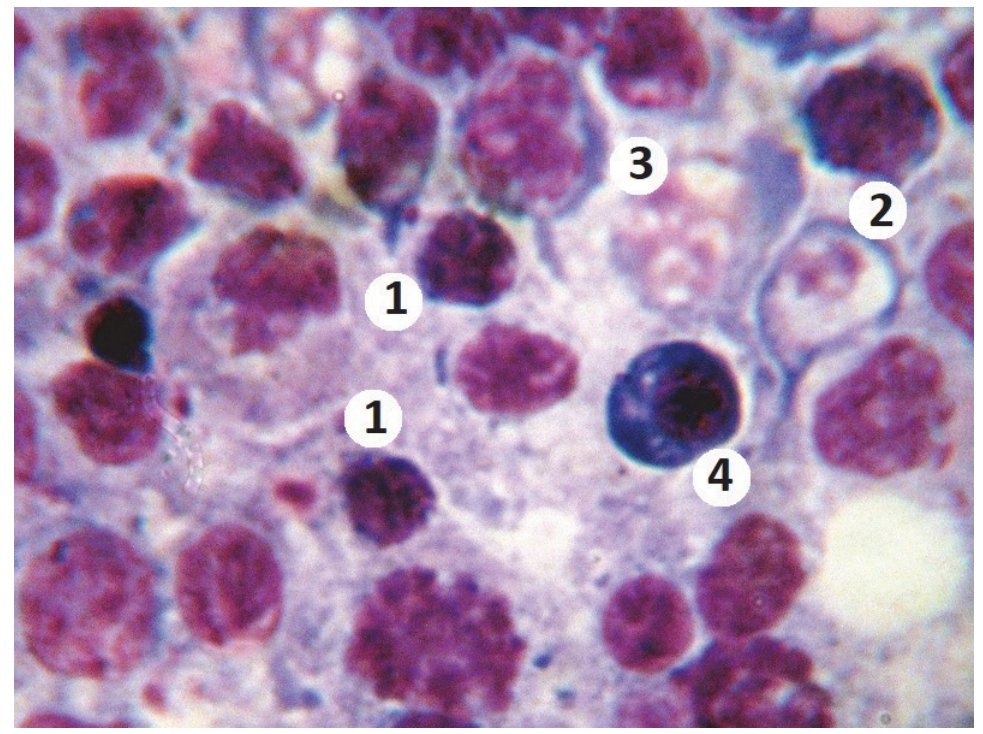

Fig. 1. Cells of the duodenal Peyer's patch of in duck aged 150 days:

1 - small lymphocyte; 2 -medium lymphocyte; 3 - large lymphocyte; 4 - plasma cell. Imprint preparation. Wright staining, $\times 1000$ 


\section{The content of different groups of lymphocytes in the Peyer's patch of the duodenum in ducks $(M \pm m, \%)$}

\begin{tabular}{|l|c|c|c|}
\hline \multirow{2}{*}{ Age, days } & \multicolumn{3}{|c|}{ Lymphocytes } \\
\cline { 2 - 4 } & Small & Medium & Large \\
\hline 1 & $52.26 \pm 0.51$ & $40.10 \pm 0.82$ & $7.63 \pm 0.67$ \\
\hline 5 & $51.77 \pm 0.48$ & $40.04 \pm 1.03$ & $8.19 \pm 0.72$ \\
\hline 10 & $51.09 \pm 0.44$ & $40.59 \pm 0.79$ & $8.32 \pm 0.41$ \\
\hline 15 & $53.48 \pm 0.22$ & $39.07 \pm 0.21$ & $7.46 \pm 0.29$ \\
\hline 20 & $53.69 \pm 0.15$ & $38.91 \pm 0.16$ & $7.39 \pm 0.31$ \\
\hline 25 & $54.23 \pm 0.94$ & $37.87 \pm 0.67$ & $7.89 \pm 0.41$ \\
\hline 30 & $51.54 \pm 0.89$ & $37.58 \pm 0.69$ & $9.02 \pm 0.71$ \\
\hline 60 & $49.75 \pm 0.92$ & $35.12 \pm 1.58$ & $15.13 \pm 1.05$ \\
\hline 90 & $44.92 \pm 1.27$ & $38.53 \pm 1.41$ & $16.56 \pm 1.18$ \\
\hline 120 & $46.63 \pm 0.39$ & $39.61 \pm 0.73$ & $14.76 \pm 0.57$ \\
\hline 150 & $45.75 \pm 1.11$ & $38.41 \pm 0.78$ & $15.84 \pm 0.77$ \\
\hline 180 & $46.12 \pm 0.27$ & $38.21 \pm 0.17$ & $15.67 \pm 0.21$ \\
\hline 210 & $47.56 \pm 0.55$ & $36.14 \pm 0.28$ & $16.29 \pm 0.78$ \\
\hline 240 & $47.74 \pm 0.38$ & $36.92 \pm 0.35$ & $15.34 \pm 0.15$ \\
\hline 330 & $47.82 \pm 0.36$ & $36.42 \pm 0.19$ & $15.76 \pm 0.44$ \\
\hline 420 & $48.65 \pm 0.49$ & $36.96 \pm 0.43$ & $14.38 \pm 0.68$ \\
\hline
\end{tabular}

Note: ${ }^{*} \mathrm{P}<0.05$ compared to the previous age group.

It, in the form of a narrow basophilic strip of unequal thickness, completely or partially delimits the nucleus. It reveals a small number of large round mitochondria with a light matrix and weakly expressed crystals, elements (tubules and cisterns) of the endoplasmic reticulum, elements of the Golgi complex, lysosomes, polyribosomes. The nucleus is light spherical, contains mainly two nucleoli, chromatin is evenly distributed in the nucleoplasm. Part of the heterochromatin is fixed near the inner membrane of the nuclear envelope.

The content of immunoblasts in the lymphoid tissue of the duodenal Peyer's patch in ducks is less than that of lymphocytes (Table 1). In birds of all studied age groups, the content of immunoblasts decreases unevenly from one day $(32.64 \pm 0.36 \%)$ to 420 days of age $(24.48 \pm 0.08 \%)$. The content of immunoblasts decreases most intensively in ducks from 25 to 30 days of age (by $7.4 \%$ ).

Plasmocytes - effector cells of B-lymphocytes, and proplasmocytes precursors of plasma cells. Proplasmocytes are small, irregularly shaped cells. Their nucleus with jagged edges has an irregular shape. The nucleus contains one or two nucleoli, in the nucleoplasm, there is a lot of heterochromatin that, fixing to the inner membrane of the nucleolemma, forms triangular and trapezoidal shapes. The cytoplasm is basophilic and larger than that of lymphocytes. Elements of the granular endoplasmic reticulum and mitochondria are localized in the cytoplasm. 


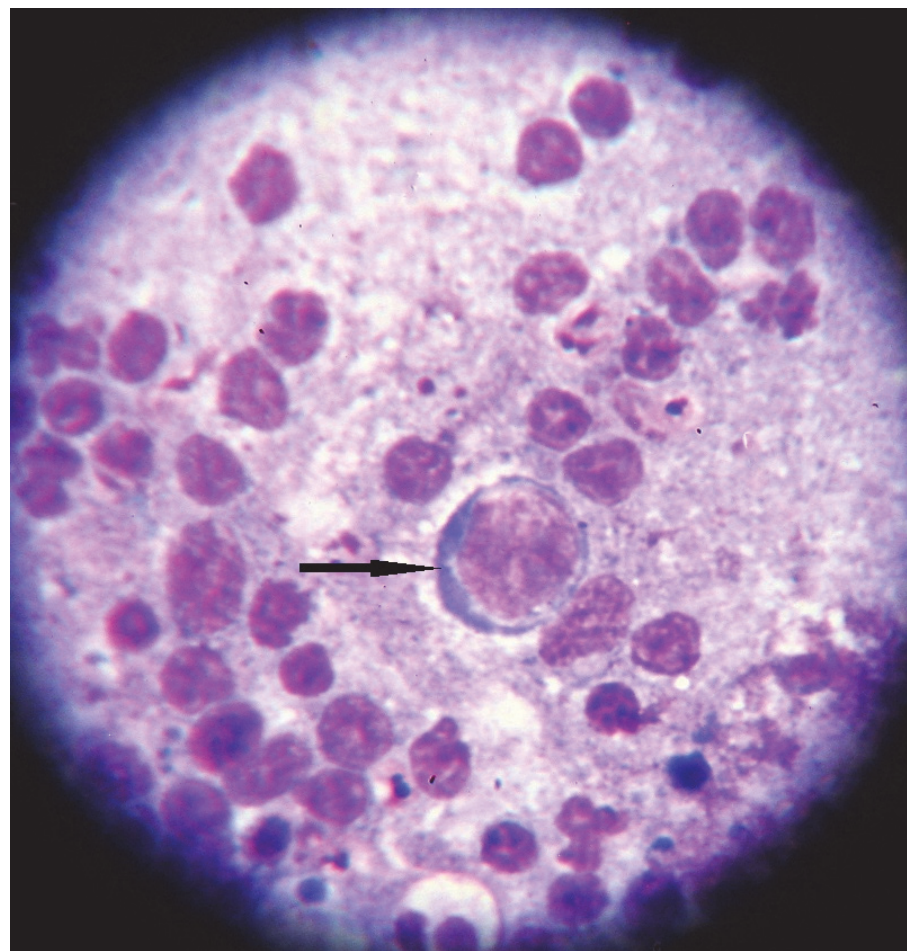

Fig. 2. Immunoblast (arrow) of the duodenal Peyer's patch in a 90-day-old duck. Imprint preparation. Wright staining, $\times 1000$

Plasmocytes - cells of small size, round, or oval shape with an eccentrically located nucleus (Fig. 1). In the latter, well-condensed heterochromatin is pronounced, forming a characteristic pattern in the form of wheel spokes or a clock face. In the cytoplasm near the nucleus, a visible area of enlightenment is the Golgi complex. The volume of the cytoplasm exceeds the volume of the nucleus and it is almost completely filled with the granular endoplasmic reticulum, the tubules of which are significantly expanded. The latter are located mainly concentrically around the nucleus. A few large mitochondria of oval and round shape with a light matrix, ribosomes, and their clusters are also visible in the cytoplasm.

Plasmocytes and proplasmocytes in the lymphoid tissue of the duodenal
Peyer's patch in ducks are detected from the 15 th days of age in small quantities $(2.52 \pm 0.11 \%)$ (Table 1$)$. With the increase in the age of birds, the content of these cells increases significantly (by $341.66 \%$ ) and in 420-day-old ducks is $11.13 \pm 0.35 \%$. In ducks in age from 10 to 15 days, the most intense, almost double (by $90.36 \%$ ) increase in the content of proplasmocytes and plasma cells is registered.

Monocytes are precursors of macrophages. They are large cells with a bean-shaped or horseshoe-shaped nucleus. In the nucleus, the lumps of heterochromatin are evenly distributed throughout the nucleoplasm. There are rounded mitochondria with a light matrix, lysosomes, and endoplasmic reticulum in the cytoplasm. 


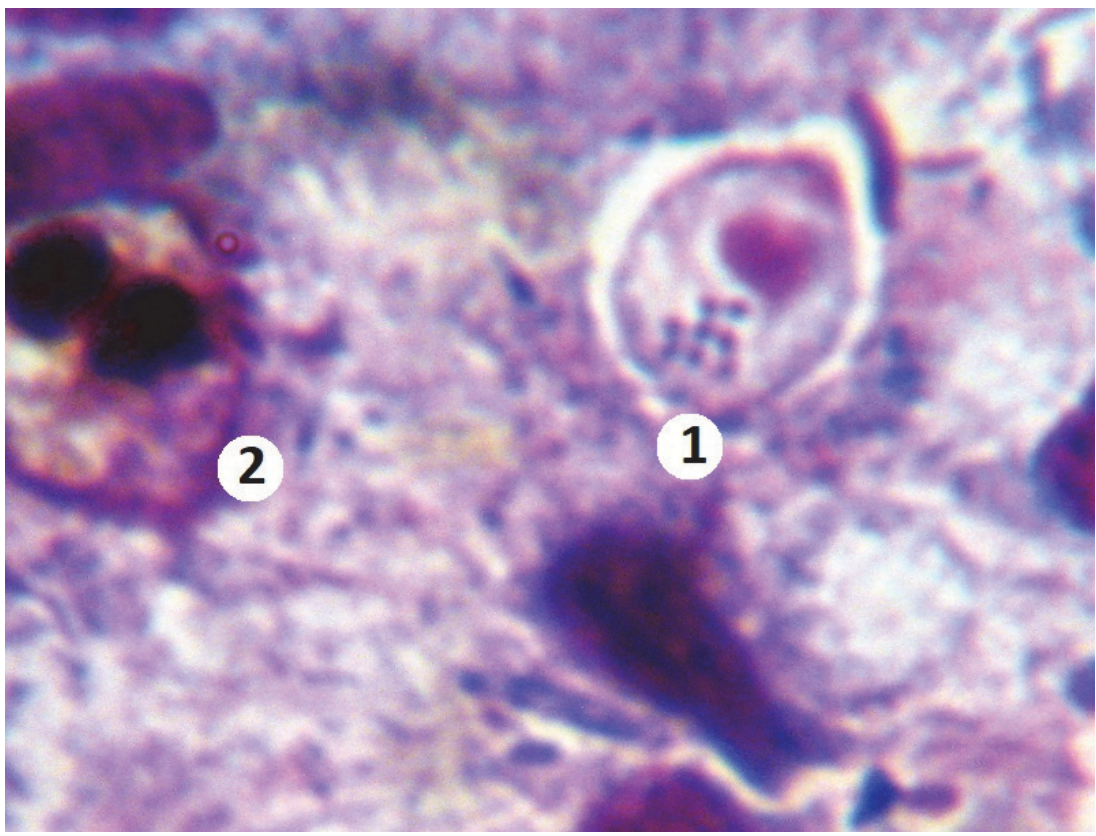

Fig. 3. Cells of the duodenal Peyer's patch in a 210-day-old duck. Imprint preparation: 1 - macrophage; 2 - pseudoeosinophil. Wright staining, $\times 1000$

Macrophages are large, round, or oval-shaped cells with jagged edges (Fig. 3). The nucleus of macrophages is small, it has a lot of heterochromatin, which is fixed to the inner membrane of the nuclear envelope and sprayed into the nucleoplasm. The cytoplasm has a significant volume and forms protrusions of various sizes and shapes. It has many large round lysosomes, small phagosomes, slightly fewer mitochondria, and tubules of the endoplasmic reticulum.

The content of macrophages and monocytes in the lymphoid tissue of the duodenal Peyer's patch in ducks of the studied age groups is also insignificant. This figure increases unevenly from $2.04 \pm 0.09 \%$ in 1-day-old birds to $8.42 \pm 0.28 \%$ in 420-day-old birds. The most intensive increase in the number of monocytes and macrophages in lymphoid tissue of the duodenal Peyer's patch of ducks is registered in age from 90 to 120 days (by 50.98\%).

\section{Conclusions}

1. Among the cells of the lymphoid tissue of the duodenal Peyer's patch are immunoblasts, lymphocytes, proplasmocytes and plasma cells, monocytes, and macrophages. The content of populations of these cells is not the same.

2. Lymphocytes in the imprint preparations are found the most. They are represented by small, medium, and large forms. Small lymphocytes were found in the largest number, and large - in the smallest. The total content of lymphocytes decreases by $14.31 \%$ with the age of ducks. The content of small and medium lymphocytes decreases unequally by 6.91 and $7.83 \%$, respectively, and large - unevenly increases by $88.47 \%$.

3. The content of immunoblasts in the lymphoid tissue of the duodenal Peyer's patch is unequally reduced by $25.0 \%$ with the age of ducks. 
4. Proplasmocytes and plasmocytes in the lymphoid tissue of the duodenal Peyer's patch in ducks are detected from the 15 th days of age. Their content increases by more than 4 times (by $341.67 \%$ ) with the age of birds.

5. The content of macrophages and monocytes in the lymphoid tissue of the duodenal Peyer's patch of ducks unequally increases more than 4 times (by $312.75 \%$ ) with the age.

\section{References}

Avtandilov, G. G. (1990). Medical morphometry [Medicinskaya morfometriya]. Moscow: Medicine.

Barsukova, V. V. \& Prokushenkova, O. H. (2015). Features of localization of aggregated lymph nodules of the small intestine in musk ducks [Osoblyvosti lokalizatsii ahrehovanykh limfatychnykh vuzlykiv tonkoi kyshky muskusnykh kachok]. Scientific and technical bulletin of the Research Center for Biosafety and Environmental Control of Agricultural Resources, 3(2): 7-11. (in Ukrainian)

Burns, R. B. \& Maxwell, M. H. (1986). Ultrastructure of Peyer's patches in the domestic fowl and turkey. Journal of Anatomy, 147:235-243.

Council of Europe. (1987). European convention for the protection of vertebrate animals used for experimental and other scientific purposes:[Strasbourg, 18. III. 1986]. Council of Europe.

Davison, F., Kaspers, B. \& Schat, K. A. (2008). Avian Immunology. Great Britain: Elsevier.

Day, M. J. \& Schultz, R. D. (2014). Veterinary Immunology: Principles and Practice. London: Manson Publishing.

Forchielli, M. L. \& Walker, W. A. (2005). The role of gut-associated lymphoid tissues and mucosal defence. British Journal of Nutrition, 93(1):41-48.

Havrylin, P. M., Prokushenkova, O. H. \& Barsukova, V. V. (2014). Features of formation and localization of aggregated lymph nodules of the small intestine in the early postnatal ontogenesis of musk ducks [Osoblyvosti formuvannia i lokalizatsii ahrehovanykh limfatychnykh vuzlykiv tonkoi kyshky $v$ rannomu postnatalnomu ontohenezi muskusnykh kachok]. Problems of zooengineering and veterinary medicine. Series: Veterinary Sciences, 28(2):356-362 (in Ukrainian).

Kaushansky, K., Lichtman, M. A., Prchal, J. T., Levi, M. M., Pres, O. W., Burns, L. J. \& Caligiuri, M. (2016). Williams Hematology, 9th edn. McGraw-Hill Education, New York.

Neutra, M. R., Mantis, N. J. \& Kraehenbuhl, J. P. (2001). Collaboration of epithelial cells with organized mucosal lymphoid tissue. Nature Immunology, 2(11):1004-1009.

Qu, W. (2018). Characterization of antigen-presenting cells in chicken peyer's patches by immunohistochemical staining. A Thesis Master of Science.

Regoli, M., Borghesi, C., Bertelli, E. \& Nicoletti, C. (1994). A morphological study of the lymphocyte traffic in Peyer's patches after an in vivo antigenic stimulation. The Anatomical Record, 239(1):47-54.

Reznikov, O. H. (2003). General ethical principles of experiments on animals. The first National Congress on Bioethics [Zahalni etychni pryntsypy eksperymentiv na tvarynakh. Pershyi natsionalnyi konhres z bioetyky]. Endocrinology, 8(1):142-145. (In Ukrainian)

Silverman, J. F. \& Frable, W. J. (1990). The use of the diff.quik stain in the immediate interpretation of fine.needle aspiration biopsies. Diagnostic Cytopathology, 6:366-369.

Storch, A., Kornhass, M. \& Schwarz, J. (2005). Testing for acanthocytosis. Journal of Neurology, 252(1):84-90.

Trufakin, V. A., Shurlygina, A. V. \& Robinson, M. V. (2005). Functional morphology of cells of the immune system in experiment and clinic [Funkcional'naya morfologiya kletok immunnoj sistemy $v$ eksperimente i klinike]. Morphology, 128(4):20-25. (in Russian) 


\section{T. А. МазУркевич (2020). КЛІТИННИЙ СКЛАД ЛІМФОїДНОї ТКАНИНИ ПЛЯМКИ} ПЕЙЄРА ДВАНАДЦЯТИПАЛОї КИШКИ КАЧОК. Ukrainian Journal of Veterinary

Sciences, 11(3): 24-32, https://doi.org/10.31548/ujvs2020.03.003

Анотація. Метою нашого дослідження було вивчити клітинний склад лімфоїдної тканини плямки Пейєра дванадиятипалої кишки качок у віковому аспекті. Серед клітин лімфоїдної тканини плямки Пейєра дванадиятипалої кишки виявляються імунобласти, лімфоцити, проплазмоцити та плазматичні клітини, моноцити та макрофаги, епітеліальні клітини, ретикулярні клітини, еритроцити, гранулоцити, фібробласти та М-клітини. Вміст популяцій цих клітин неоднаковий. Лімфоцитів у препаратах-відбитках виявляється найбільше. Вони представлені малими, середніми і великими формами. Малих лімфоцитів реєструється найбільше, а великих - найменше. Вміст малих і середніх лімфоцитів із віком качок нерівномірно зменшується, а великих лімфоцитів-нерівномірно збільшується. Вміст імунобластів у лімфоїдній тканині плямки Пейєра дванадиятипалої кишки качок менший такого лімфоцитів. Цей показник нерівномірно зменшується від першої до 420 доби життя птиці. Проплазмоцити і плазмоцити в лімфоїдній тканині плямки Пейєра дванадиятипалої кишки виявляються в невеликій кількості з 15-добового віку качок. Їхній вміст значно збільшується зі збільшенням віку птиці. Вміст макрофагів та моноцитів у лімфоїдній тканині плямки Пейєра дванадцятипалої кишки качок незначний. Від першої до 420 доби життя птиці реєструється нерівномірне збільшення цього показника. Водночас, вміст ретикулярних клітин підрахувати неможливо, оскільки вони прикриті лімфоїдними клітинами, а фібробласти, еритроцити, гранулоцити $і$ М-клітини трапляються в препаратах-відбитках у незначній кількості, яка не піддається статистичній обробиі.

Ключові слова: качки, дванадиятипала кишка, плямка Пейєра, лімфоїдна тканина, імунобласти, лімфоцити, проплазмоцити, плазмоцити, моноцити, макрофраги 